\title{
Efektivitas Aplikasi Microsoft Teams Terhadap Motivasi Belajar Pada Pembelajaran Daring Siswa Kelas Vb SDN Sumberejo II Surabaya
}

\author{
Fatihatul Mufida, Evi Rizqi Salamah \\ STKIP Bina Insan Mandiri Surabaya \\ fmufidah25@gmail.com
}

\section{Article History}

received 29/10/2021

revised 11/11/2021

accepted $24 / 12 / 2021$

\begin{abstract}
The research to describe the application of Microsoft Teams in describing the response of students by using the application of Microsoft Teams in online learning. To describe the obstacles experienced by using the Microsoft Teams application in online learning. This research uses descriptive research methods with qualitative descriptive analysis techniques. The data source is done purposively. Data collection techniques with triangulation (combined) data analysis is inductive / qualitative, namely through interviews, questionnaires, and documentation. The results of the study stated that the Microsoft Teams application in online learning with the research subject was the class VB students of SDN Sumberejo II Surabaya and their homeroom teachers. From the results of this study, it can be concluded that learning using the Microsoft Teams application is very effective. The results of the study were shown from interviews with the homeroom teacher and the distribution of questionnaires that the researchers distributed after the learning process using the Microsoft Teams application was completed. From the results of interviews with the homeroom teacher, it was found that online learning using the Microsoft Teams application is easier to convey material, learning is more interesting and the student learning process is more effective in the online learning process. From the results of the questionnaire, 20 of 23 students stated that they strongly agree and agree that online learning uses the Microsoft Teams application. Constraints experienced during the online learning process using the Microsoft Teams application are only due to the network
\end{abstract}

Keywords: Microsoft Teams Application, online learning, media

\begin{abstract}
Abstrak: Penelitian ini bertujuan untuk mendeskripsikan penggunaan aplikasi microsotf teams dan respon siswa dalam penggunaanya dalam pembelajaran daring. Untuk mendeskripsikan kendala yang dialami dalam penggunaan aplikasi Microsoft teams dalam pembelajaran daring. Penelitian ini menggunakan metode penelitian deskriptif dengan teknik analisis deskriptif kualitatif. Sumber data dilakukan secara purposive. Teknik pengumpulan data dengan triangulasi (gabungan) analisis data bersifat induktif/ kualitatif yaitu melalui wawancara, angket, dan dokumentasi. Hasil penelitian menyatakan bahwa Aplikasi Microsoft teams dalam pembelajaran daring dengan subjek penelitian yaitu pada siswa kelas VB SDN Sumberejo II Surabaya dan wali kelasnya. Dari hasil penelitian tersebut dapat disimpulkan bahwa pembelajaran menggunakan aplikasi Microsoft teams sangat efektif. Hasil dari penelitian ditunjukan dari wawancara dengan wali kelas dan pembagian angket yang peneliti bagikan setelah proses pembelajaran menggunakan aplikasi Microsoft teams selesai. Dari hasil wawancara dengan wali kelas didapat bahwa pembelajaran daring menggunakan aplikasi Microsoft teams lebih mudah menyampaikan materi, pembelajaran lebih menarik dan proses belajar siswa lebih efektif dalam proses pembelajaran daring. Dari hasil angket yaitu 20 dari 23 siswa menyatakan bahwa sangat setuju dan setuju apabila pembelajaran daring menggunakan aplikasi Microsoft teams. Kendala yang dialami saat proses pembelajaran daring dengan menggunakan aplikasi Microsoft teams hanya karena jaringan.
\end{abstract}

Kata Kunci : Aplikasi Microsoft Teams, media, pembelajaran daring 


\section{PENDAHULUAN}

Pertengahan tahun 2020 tepatnya dibulan maret ini seluruh dunia sedang menghadapi sebuah wabah, khususnya pandemi Covid-19. Pandemi Covid-19 adalah keadaan darurat kesejahteraan yang telah melanda hampir semua sisi dunia. Pandemi ini sangat mempengaruhi berbagai bidang, salah satunya dalam pendidikan. Negara Indonesia telah memilih untuk menutup sekolah dan kampus selama pandemi COVID19. Untuk beradaptasi dengan pandemi Covid-19, negara Indonesia melakukan suatu kegiatan, tepatnya melalui penyelesaian pembangunan social distancing, yang menyiratkan jarak sosial yang dimaksudkan untuk mengurangi komunikasi individu di wilayah lokal yang lebih luas. Dengan adanya pemisahan sosial, pembelajaran di sekolah menjadi terhambat dan tidak mungkin langsung bertatap muka di sekolah, hal ini sangat mempengaruhi pelaksanaan belajar.

Karena pandemi Covid-19, diberikan Kejadian Luar Biasa (KLB) sehingga terjadi kehebohan di segala bidang khususnya bidang pendidikan, sekolah diliburkan, aktivitas pembelajaran di sekolah terganggi, proses belajar yang semula bertatap muka untuk sementara waktu tidak dilakukan. Untuk mengatasi masalah ini, penting untuk mengubah rencana model dalam kegiatan mendidik dan belajar untuk menghindari pembelajaran tatap muka sebagai upaya untuk mengurangi penyebaran infeksi Coronavirus (Martin \& Tapp, 2019). menyatakan terkait pembelajaran jarak jauh. Dan Kemnedikbud memberikan Surat Edaran Nomor 4 Tahun 2020 perihal pelaksanaan strategi persekolahan di masa krisis penyebaran penyakit Covid-19 yang salah satu substansinya belajar di rumah atau belajar online atau pembelajaran jarak jauh (PJJ) (Alifah, 2021).

Pembelajaran jarak jauh (PJJ) dapat diartikan sebagai sesuatu yang baru di Indonesia, karena pendidikan dengan inovasi adalah ekonomis satu sama lain. Karena Pembelajaran harus dilanjutkan, Pembelajaran Jarak Jauh (PJJ) sangat tepat untuk meneruskan pembelajaran saat ini. Pembelajaran yang biasa dilakukan di sekolah saat ini adalah belajar di rumah dengan memanfaatkan berbagai aplikasi seperti ruang guru, classroom, zoom, google doc, google form, dan melalui whatsapp gathering. Namun dalam aplikasi-aplikasi tersebut masih banyak terdapat kekurangan, seperti halnya di grup wahtasapp, siswa seringkali mengabaikan ketika mendapatkan tugas dari bapak ibu guru dan penggunaan whatsaap dirasa kurang efektif dan maksimal karena kurang adanya interaksi secara langsung dianatar guru dan siswa, sedangkan saat penggunaan aplaikasi zoom juga demikian ada inetraksi namun hanya empat puluh lima menit sudah mati secara otomatis sehingga materi belum slesai disampaikan zoom mati dan siswa enggan untuk bergabung lagi, maka dari itu peneliti menyarankan agar pembelajaran dilakukan dengan menggunakan Aplikasi Microsof Teams, dengan berbagai kelebihan pada aplikasi ini karena pembelaran harus tetap berjalan

Dinas pendidikan Kota Surabaya telah bekerja sama dengan pihak Microsoft dalam meningkatkan mutu pendidikan di Kota Surabaya. Dalam penelitian ini, tergolong baru karena belum ada penelitian sebelumnya yang ditemukan tentang pembahasan media online seperti microsoft teams. Dari hasil sharing dengan beberapa guru, terdapat beberapa kelebihan dalam penggunaan media microsoft teams, mudah untuk diakses dan digunakan, serta mempermudah guru dalam melaksanakan proses pembelajaran khusunya dalam menyampaikan materi dan sekaligus pelaksanaan evaluasinya.

Efektivitas berasal dari kata dasar efektif. Dalam referensi kata bahasa Indonesia, kata layak memiliki arti penting memiliki dampak, akibat atau pengaruh. Jadi efektivitas dapat diartikan seberapa besar tingkat pencapaian yang dapat (dicapai) dari suatu strategi atau bisnis tertentu sesuai dengan tujuan yang ingin dicapai. Seperti yang ditunjukkan oleh Kamus Besar Bahasa Indonesia (KBBI) efektifitas menunjukkan tingkat pencapaian suatu tujuan. Sebuah karya dikatakan berdaya jika karya tersebut telah sampai pada tujuannya. 
Efektivitas seperti yang ditunjukkan oleh Pringgodogjo menunjukkan tingkat pencapaian suatu daya tarik jika mencapai tujuannya. Menurut Ravianto, efektivitas adalah cara baik pekerjaan dilakukan, sejauh mana individu menghasilkan hasil yang sesuai dengan bentuknya. Artinya, jika suatu tugas dapat diselesaikan sesuai pengaturan, baik pada jadwal, biaya, dan kualitas, dan karakter serta perkembangan anak itu cenderung dianggap kuat (Salamah, 2017b). Lebih lanjut Madya Kasihadi menggarisbawahi bahwa efektivitas adalah suatu kondisi yang menunjukkan sejauh mana apa yang diatur dapat dicapai, semakin banyak rencana yang dapat dicapai, semakin layak tindakan tersebut.

(Salamah, 2017a) Dengan demikian, dapat disimpulkan bahwa pemanfaatan media pembelajaran adalah suatu karya, sejauh mana upaya pembelajaran dengan memanfaatkan instrumen (media) dalam mencapai suatu tujuan yang telah disusun. Sebagai tolak ukur dalam pembelajaran ini adalah pemahaman siswa dalam mendapatkan topik yang diselesaikan secara online saat ini.

Aplikasi Microsoft Teams adalah tahap komunikasi dan upaya terkoordinasi yang menyatukan unsur-unsur diskusi kerja, video gathering, penimbunan catatan (mengingat kerjasama untuk dokumen), dan rekonsiliasi aplikasi. Aplikasi ini tergabung dengan keanggotaan Office 365 dan juga bisa dikoordinasikan dengan item selain yang dibuat oleh Microsoft. Microsoft Teams adalah pesaing Slack, dan merupakan konsekuensi dari kemajuan dan peningkatan Microsoft Skype for Business.

Microsoft mendeklarasikan Teams pada sebuah kesempatan di New York, dan secara resmi mengirimkannya pada 14 Maret 2017. Aplikasi ini dibuat pada hackathon interior, dan saat ini dijalankan oleh Brian MacDonald, Wakil Presiden Perusahaan Microsoft. (id.wikiepdia.com).

Aplikasi Microsoft Teams adalah hubungan lanjutan yang mencoba menyatukan diskusi, konten, tugas, dan aplikasi di satu tempat, memungkinkan pendidik untuk membangun lingkungan belajar yang unik dalam satu tahap. Microsoft bermaksud untuk menawarkan pengalaman belajar jarak jauh secara individu, menggambar dan berhubungan secara sosial seperti berkonsentrasi di kelas online. (Hubbard et al., 2021) mengatakan bahwa Microsoft Teams mengizinkan siswa dan pedidik untuk tetap berhubungan dan membantu satu sama lain menggunakan diskusi, dan dapat merasa seperti mereka bertemu langsung. Pendidik dapat mengawasi perkembangan siswa dalam kesehariannya menggunakan Tugas. Selain itu, seperti di kelas, pengajar dapat memanfaatkan aplikasi dan kapasitas Teams untuk membantu cara kerja mereka (Office 365 Teams, 2020).

Di Teams, pendidik bisa tanggap dalam berbicara dengan siswa, berbagi catatan dan situs, membuat Buku Catatan Kelas OneNote, dan menyebarluaskan serta mengevaluasi tugas. Buku Catatan Kelas yang tergabung dalam OneNote dan mulai menyelesaikan tugas, para manajamen tugas memberdayakan pendidik untuk menyusun aktivitas intuitif dan memberikan masukan yang kuat dan tepat waktu. Administrator dan staf sekolah dapat tetap terdidik dan bekerja sama dengan memanfaatkan Tim Staf untuk kolaborasi diskusi yang efektif. Pendidik dapat berbagi materi dengan memanfaatkan Komunitas Pembelajaran Profesional. Tim Kelas dapat dimanfaatkan untuk membuat ruang belajar kooperatif, memberikan tahapan pertemuan virtual, bekerja dengan pembelajaran dengan tugas dan masukan, dan memimpin panggilan langsung dengan siswa (Singh \& Awasthi, 2020). Berikut adalah penampakan gambar microsoft teams for education, 


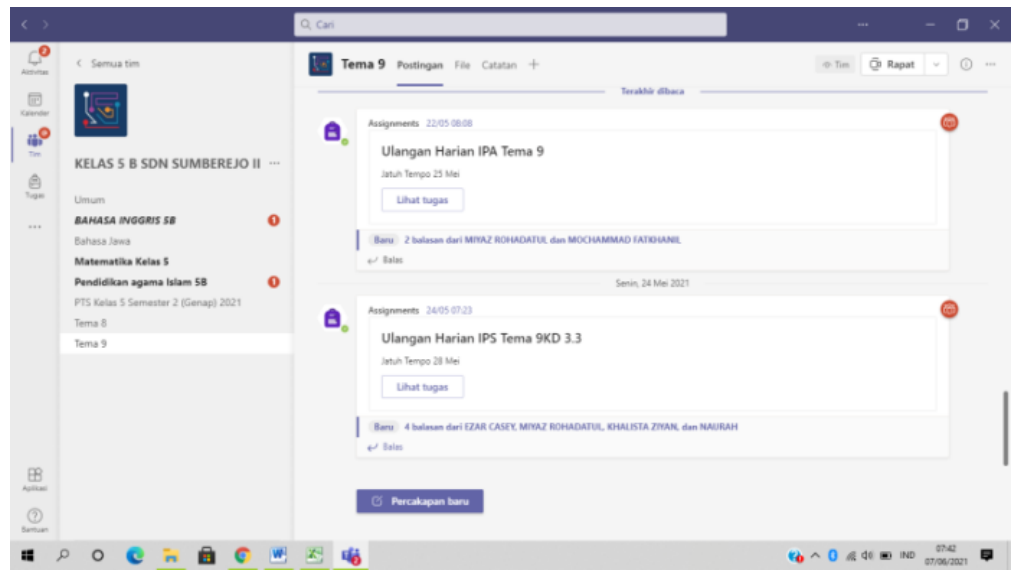

Gambar 1. Tampilan Microsoft Teams

\section{Fitur-fitur Microsoft Teams}

Dalam aplikasi Microsoft Teams ini banyak fitur-fitur yang mendukung proses pembelajaran tanpa menyulitkan peserta didik dalam mengikuti pembelajaran jarak jauh. Berikut adalah fitur Microsoft Teams, antara lain :

1. Fitur Melakukan Panggilan

Fitur Microsoft Teams sudah sangat lengkap. Dengan memanfaatkan Microsoft Team, Anda dapat menghubungi siapa saja, baik itu kolega individu maupun orang lain. Elemen ini sendiri direncanakan dengan cerdik yang dapat menggantikan gadget telepon dengan lebih sukses.

2. Fitur Mengirimkan Pesan

Fitur berikutnya adalah untuk mempermudah pengiriman pesan pada saluran yang sudah bisa dibuat. Setiap bagian di saluran dapat mengirim banyak kunjungan secara terbuka. Terbatas untuk mengirim pesan, tetapi juga mengirim gambar, stiker, emotikon, dan menghubungkan laporan penting.

3. Fitur Video Conference

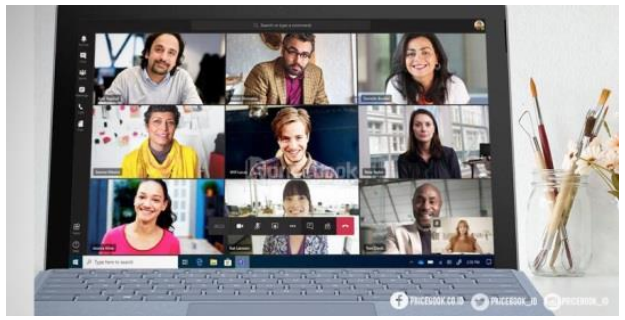

Gambar 2. Video Conference

Dalam menggunakan fitur konferensi video, Anda sekarang tidak perlu menghabiskan banyak energi untuk bertemu seseorang dalam kelompok, cukup gunakan fitur ini karena lebih mudah dan lebih sederhana. Ada juga fitur pendukung lainnya seperti mengadakan siaran langsung untuk pertemuan skala besar, membuat rencana pertemuan, dan lainnya.

4. Fitur Peredam Bising

Fitur ini cenderung untuk mengurangi keributan di belakang layar yang tentunya sangat mengganggu. Jadi Anda dapat mendengar dengan lebih jelas apa yang dikatakan selama rapat virtual.

5. Fitur Raise Hand

Fitur aplikasi Microsoft Teams ini dapat digunakan untuk memberikan tanda visual ketika Anda ingin menyampaikan sesuatu dalam sebuah rapat. Kemudian, pada saat itu, ketika orang tersebut akan mulai berbicara, sebuah bel dapat didengar. 


\section{Fitur Obrolan pada Windows Berbeda}

Fitur ini mempermudah untuk menaikkan obrolan di jendela yang berbeda. Dengan begitu, lebih mudah bagi Anda untuk beralih di antara diskusi yang sedang berlangsung.

7. Terintegrasi secara Langsung dengan Aplikasi Office 365

Aplikasi Microsoft Teams telah dikoordinasikan secara langsung dengan beberapa aplikasi di Office 365 . Dengan begitu, memudahkan pendidik untuk memberikan tugas yang telah dibuat di Form 365 langsung disampaikan ke Microsoft Teams, tidak ada alasan kuat untuk bolak-balik saat Anda perlu membuka aplikasi yang berbeda seperti Excel. , Word, Power Point, dan lainnya. Dengan berbagai ketentuan fantastis dari Microsoft Teams di atas, tentu dapat menopang kebermanfaatan sebuah grup dalam mencapai tujuannya (Shen et al., 2006).

Cara Penggunaan Aplikasi Microsoft Teams. Untuk mencapai tujuan pembelajaran di Aplikasi Microsoft Teams memiliki empat kapasitas penting dalam fondasinya, yaitu informasi khusus, koordinasi rapat, panggilan suara dan video. Kapasitas ini digabungkan ke dalam Microsoft Office 365 dekat dengan instrumen penting lainnya yang Anda gunakan untuk membantu pembelajaran (Hubbard et al., 2021). Pendekatan untuk memanfaatkan aplikasi Microsoft Teams meliputi: Buka Teams, Buat Grup, Tambahkan Anggota Tim, Tambahkan Saluran. Sedangkan kelebihan dan kekurangan aplikasi Microsoft Teams yaitu: 1. Bisa Mengelola Kelompok dengan Mudah, 2. Tersedia Pengeditan dan Berbagi File, 3. Tersedia dalam Video dan Audio Berkualitas, 4. Tersedia Saluran Khusus untuk Mengobrol Pribadi maupun Grub, 5. Keamanan Langsung dari Microsoft, 6. Membutuhkan Koneksi yang Prima, dan 7. Penggunaan Bandwidth yang Besar.

\section{METODE}

Dalam judul penelitian "Efektifitas Aplikasi Microsoft Teams Dalam Pembelajaran Daring Pada Siswa Kelas VB SDN Sumberejo II Surabaya". Ini merupakan penelitian kualitatif Menurut (Creswell \& Plano Clark, 2012) yang tertuang pada bukunya "Metodologi Penelitian Kualitatif" menjelaskan metode penelitian kualitatif adalah teknik penelitian yang bergantung pada cara berpikir postpositivisme, dilakukan melihat keadaan item reguler, (bukan uji coba) di mana peneliti sebagai instrumen kunci, teknik ini menganalisis data, sifat penelitian adalah kualitatif, dan hasilnya akan menekankan pada generalisasi.

Data yang digunakan dalam penelitian ini diperoleh dengan menerapkan teknik angket dan wawancara serta teknik dokumentasi. Pengambilan data diperoleh dari angket yang terdiri dari 14 pertanyaan dengan pilihan jawaban Sangat setuju, Setuju, Tidak setuju, Sangat tidak setuju yang dalam bentuk google form.

Dalam penelitian ini, instrumen utama adalah peneliti, namun setelah titik fokus eksplorasi menjadi jelas, layak untuk mengembangkan instrumen pengujian langsung, yang diandalkan untuk menyelesaikan informasi dan membandingkannya dengan informasi yang ada. telah ditemukan melalui persepsi (angket) dan wawancara (Creswell \& Plano Clark, 2012)

Menurut (Creswell \& Plano Clark, 2012) Dokumen adalah catatan kejadian yang telah berlalu. dokumentasi bisa melalui catatan, gambar atau karya. Dokumentasi merupakan bagian integral dari pemanfaatan angket dan wawancara.

Teknik analisis data yang digunakan oleh penulis adalah dengan model yang dikutip dari (Creswell \& Plano Clark, 2012) terdiri dari 5 tahap yaitu mengumpulkan informasi, mencatat lapangan, memilah informasi, menyusun informasi, membuat kesimpulan. 
HASIL DAN PEMBAHASAN

Pada bagian menjelaskan mengenai penjabaran sebuah gambaran Efektifitas Aplikasi Microsoft Teams Dalam Pembelajaran Daring Pada Siswa Kelas VB SDN Sumberejo II Surabaya. Narasumber penelitian kali ini adalah siswa dan guru kelas. Penelitian ini mengambil siswa kelas VB sebagai narasumber utama. Dalam hal ini, hasil penelitian yang dapat dijabarkan yaitu berhubungan tentang efektifitas Aplikasi Microsoft Teams Dalam Pembelajaran Daring Pada Siswa Kelas VB SDN Sumberejo II Surabaya. Selanjutnya dapat dijabarkan dalam pembahasan berbagai macam-macam penemuanpenemuan.

Proses penelitian dengan google form, peneliti menganalisis semua jawaban yang telah dikirim kan oleh siswa, dari hasil pengisian angket siswa dan wawancara guru pembelajaran menggunakan aplikasi microsoft teams sangat efektif dan mebantu sekali dalam proses pembelajaran. Respon siswa dan guru sangat baik dilihat dari hasil pengisian angket dan hasil wawancara peneliti dengan guru yang telah peneliti dapat dan peneliti jelaskan pada analisis data. Dari hasil penelitian, cenderung diduga bahwa pengajaran menggunakan aplikasi teams akan menonjol bagi siswa sehingga dapat menumbuhkan inspirasi belajar, pengajar lebih mudah dalam merencanakan penyajian materi dan pembelajaran akan lebih jelas maknanya sehingga siswa dapat lebih mudah memahaminya. pentingnya, dan memungkinkan siswa untuk mendominasi menunjukkan tujuan yang lebih baik. Selain itu, pengajar dapat mencapai target pembelajaran. Strategi dalam menampilkan juga akan lebih bergeser dan siswa melakukan latihan pembelajaran karena mereka menggambarkan penggambaran guru, namun juga latihan yang berbeda, misalnya mengamati, melakukan, menunjukkan akibat dari pembelajaran langsung.

Hal ini bisa ditunjukkkan dengan gambar dibawah ini mengenai respon siswa terhadap penggunaan aplikasi microsoft teams.

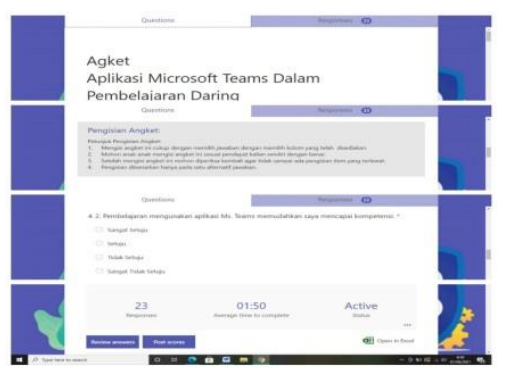

1. Mengikuti pembelajaran menggunakan aplikasi MsTeams adalah pengalaman baru saya More Details

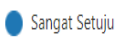

Setuju

Tidak Setivi

Sangat Tidak Setuju

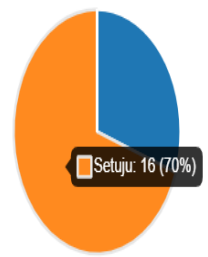

\section{Gambar 3. Angket Respon Siswa Aplikasi Microsoft Teams}

Berdasarkan hasil angket yang telah diisi oleh siswa sebagai narasumber peneliti, pengunaan aplikasi dan dalam proses pembelajarannya relatif efektif dan relevan dalam proses pembelajaran. Hasil dari penyebaran Angket dapat disimpulkan bahwa:

1. Senang dan setuju dengan adanya penggunaan Microsof Teamas karena dirasa ada pengalaman baru yang mereka dapat.

2. Siswa merasa dipermudah dalam mencapai kompetensi setelah menggunakan Microsoft Teams.

3. Penyampaian materi lebih menarik.

4. Aplikasi Microsof Teams dapat meningkatkan motivasi siswa.

5. Materi mudah difahami, dikemas lebih bervariatif dan inovatif serta mengandung makna yang dalam. 
6. Siswa banyak melakukan kegiatan dengan kata lain lenih aktif dan menjadi subjek belajar.

7. Sisiwa lebih maximal dalam berinteraksi baik dengan guru maupun dengan siswa lain, dan memduahkan mereka dalam bertanya jawab.

Berdasarkan dari beberapa hasil angket siswa banyak siswa yang setuju atas aplikasi Microsoft teams dapat membantu pembelajaran daring yang di laksanakan sekolah-sekolah yang tidak dapat melakukan tatap muka secara langsung. Dengan demikian dapat dikatakan bahwa aplikasi Microsoft teams dalam pembelajaran daring pada siswa kelas 5B SDN Sumberejo II sangat efektif.

Berikut hasil wawancara dengan guru kelas dan dapat dismpulkan bahwa:

1. Sama halnya yang dikatakan siswa pada sebarang angket, dengan penggunaan Microsof Teams dapat mempermudah guru penyampaian materi menjadi lebih jelas.

2. Penyampaian materi lebih bervariasi ketika saya menyajikan media lain seperti sway atau PPT, sehingga dapat di variasikan dengan berbagai media pebelajaran.

3. Guru dan siswa melakukan banyak kegiatan tersebut dengan bukti bisa di upload dokumentasi kegiatan di aplikasi Microsoft teams.

4. Microsoft teams sendiri dalam pembelajaran daring sangat membantu dan menarik dalam penyampaian materi pembelajaran.

5. Untuk respon siswa jelas ada pro dan kontra tentang itu, tetapi banyak siswa yang antusias saat pembelajaran menggunakan aplikasi Microsoft teams.

6. luar biasa karena bisa di setting kelas dan aktifitasnya. Tampilan aplikasi Microsoft teams menarik sehingga antusias siswa sangat senang mengikuti pembelajaran daring.

Berdasarkan data dari hasil penelitian, peneliti akan memberikan gambaran secara umum yang telah diperoleh. Data yang di dapat peneliti saat pembelajaran daring berlangsung adalah pembelajaran berjalan lancar dan lebih menarik dengan menggunakan aplikasi Microsoft teams. Siswa-siswa dapat termotivasi untuk belajar, pembelajaran lebih jelas dan mudah dipahami siswa, lebih banyak kegiatan yang dilakukan siswa dan wali kelas apabila pembelajaran daring menggunakan aplikasi Microsoft teams hal tersebut selaja dengan penelitian yang dilaksanakan oleh (Shen et al., 2006).

Data yang telah diperoleh peneliti dari hasil wawancara dengan wali kelas bahwa wali kelas setiap hari melakukan pembelajaran daring dengan siswa, wali kelas memanfaatkan aplikasi microsot teams yang telah di fasilitasi dari Dinas Pendidikan Surabaya dalam pelaksanaan pembelajaran daring. Dengan pembelajaran daring menggunakan aplikasi Microsoft teams pembelajaran menjadi lebih menarik, dapat menumbuhkan motivasi belajar siswa, membuat pengajaran lebih jelas maknyanya, membantu pengajaran lebih mudah dipahami maknanya, membantu siswa menguasai tujuan pembelajaran, metode pengajaran lebih variasi karena dapat di variasikan dengan sway atau PPT dan media pembelajaran lainnnya, dan lebih banyak kegiatan yang di lakukan seperti mengamati, melakukan, dan memdemotrasikan pembelajaran. Wali kelas berpendapat bahwa aplikasi Microsoft teams sangat efektif dalam membantu wali kelas dalam proses pembelajaran daring.

Data yang diperoleh dari hasil angket siswa bahwa dari 23 siswa 20 siswa setuju dan senang pembelajaran daring menggunakan aplikasi Microsoft teams karena pembelajaran daring lebih menarik, siswa mudah bertanya jawab dengan wali kelas, lebih mudah dipahmi maknanya, siswa mudah menguasai tujuan pembelajaran, menumbuhkan motivasi belajar siswa, dan banyak yang dilakukan siswa dalam pembelajaran daring.

Penggunaan aplikasi Microsoft teams dalam pembelajaran daring membutuhkan sinyal atau jaringan yang kuat agar dapat mengikuti pembelajaran dengan jelas tanpa 
ada kendala. Apabila jaringan itu sangat kuat siswa dapat mendengar penjelasan wali kelas tanpa putus-putus suaranya, gambar yang di tampilkan terlihat jernih dan bagus, tidak bising ketika guru menjelaskan, sehingga siswa bisa fokus dalam pembelajaran daring. Jadi pada dasarnya untuk kendala pada pengunaan aplikasi Microsoft teams dalam pembelajaran daring adalah peru sinyal yang kuat seperti penelitian yang telah dilakukan oleh (Buchal \& Songsore, 2019).

Dalam hal ini peneliti hanya sebatas mendeskripsikan respon siswa dalam penggunaan Microsof Teams dalam pembelajaran daring. Dalam penelitian ini ditemukah bahwa adanya motivasi yang meningkat dan rspon siswa yang sangat menyukai adanya penggunaan aplikasi Microsof Teams dalam pembelajaran. Peneliti menyarjakn pada penelitian berikutnya untuk dapat mencari informasi dana melakukan penelitian terkait hubungan antara aktivitas atau respon siswa pada penggunaan Microsof Team, serta bagaimana kompetensi dan kempuan guru dalam penggunaannya.

\section{SIMPULAN}

Berdasarkan kajian teoritis dan penelitian yang telah dilakukan untuk membahas Efektifitas Aplikasi Microsoft Teams Dalam Pembelajaran Daring Pada Siswa Kelas VB SDN Sumberejo II Surabaya dapat disimpulkan sebagai berikut:

1. Aplikasi Microsoft teams dalam pembelajaran daring dengan subjek penelitian yaitu pada siswa kelas VB SDN Sumberejo II Surabaya dan wali kelasnya. Dari hasil penelitian maka kesimpulannya yaitu pembelajaran memanfaatkan aplikasi Microsoft teams sangat efektif.

2. Hasil dari penelitian ditunjukan dari wawancara dengan wali kelas dan pembagian angket yang peneliti bagikan setelah proses pembelajaran menggunakan aplikasi Microsoft teams selesai. Dari hasil wawancara dengan wali kelas didapat bahwa pembelajaran daring menggunakan aplikasi Microsoft teams lebih mudah menyampaikan materi, pembelajaran lebih menarik dan proses belajar siswa lebih efektif dalam proses pembelajaran daring. Dari hasil angket yaitu 20 dari 23 siswa menyatakan bahwa sangat setujudan setuju apabila pembelajaran daring menggunakan aplikasi Microsoft teams.

3. Kendala yang dialami saat proses pembelajaran daring dengan menggunakan aplikas Microsoft teams hanya karena jaringan atau sinyal. Penggunaan aplikasi Microsoft teams ini sangat membutuhkan jaringan yang stabil.

\section{DAFTAR PUSTAKA}

Alifah, U. (2021). panduan pengajuan prosposal jarak jauh. 3(2), 6.

Buchal, R., \& Songsore, E. (2019). Using Microsoft Teams To Support Collaborative Knowledge Building in the Context of Sustainability Assessment. Proceedings of the Canadian Engineering Education Association (CEEA), 1-8. https://doi.org/10.24908/pceea.vi0.13882

Creswell, J., \& Plano Clark, V. L. (2012). 51-Creswell \& Plano Clark, 2012.pdf.

Hubbard, M., Bailey, M. J., Hess, D., \& Hellebro, M. (2021). Mastering Microsoft Teams. In Mastering Microsoft Teams. https://doi.org/10.1007/978-1-4842-6898-8

Martin, L., \& Tapp, D. (2019). Teaching with Teams: An introduction to teaching an undergraduate law module using Microsoft Teams [Enseñar con equipos: una introducción a la enseñanza de un módulo de derecho de pregrado con Microsoft Teams]. Innovative Practice in Higher Education Journal, 3(3), 58-66.

Salamah, E. R. (2017a). Pengembangan Media Pembelajaran Berbasis Audio Visual Tokoh-Tokoh Kemerdekaan Indonesia Evi. E-Journal.Unipma, 7(1), 1-8. http://ejournal.unipma.ac.id/index.php/PE

Salamah, E. R. (2017b). perkembangan belajar anak. In PEDAGOGIA: Jurnal 
Pendidikan (Vol. 6, Issue 1). https://doi.org/10.21070/pedagogia.v6i1.616

Shen, J., Hiltz, S. R., \& Bieber, M. (2006). Collaborative online examinations: Impacts on interaction, learning, and student satisfaction. IEEE Transactions on Systems, Man, and Cybernetics Part A:Systems and Humans, 36(6), 1045-1053. https://doi.org/10.1109/TSMCA.2006.883180

Singh, R., \& Awasthi, S. (2020). Updated Comparative Analysis on Video Conferencing Platforms- Zoom, Google Meet, Microsoft Teams, WebEx Teams and GoToMeetings. Easy Chair: The World for Scientist, 1-9. 